\title{
Cave-dwelling heleomyzid flies (Diptera: Heleomyzidae) from the Polish caves. Historical overview and new data
}

\author{
Joanna Kocot-Zalewska (D) ${ }^{{ }^{*}}$ and Andrzej J. Woźnica (D) ${ }^{2}$ \\ ${ }^{1}$ Upper Silesian Museum, Department of Natural History, pl. Jana III Sobieskiego 2, 41-902 Bytom, Poland \\ ${ }^{2}$ Wrocław University of Environmental \& Life Sciences, Institute of Environmental Biology, ul. Kożuchowska 5b, 51-631, Wrocław, Poland
}

\begin{abstract}
This article details the analysed results of the recent study on heleomyzid flies (Diptera: Heleomyzidae) that occurred in the caves of Kraków-Częstochowa Upland. Additionally, all accessible information about those flies from the Polish caves has been compiled. In effect, 23 species from seven genera were identified. Among these determined species, one was considered as troglobiont, eleven as eutroglophiles, nine as subtroglophiles, and two as trogloxenes. Dominant species were Scoliocentra brachypterna, Heleomyza captiosa, and Eccoptomera pallescens. The highest number of species has currently been found in the Kraków-Częstochowa Upland
\end{abstract}

Keywords: $\quad$ eutroglophile, Kraków-Częstochowa Upland, subtroglophile, Sudety Mts, Tatra Mts Received 21 February 2021; Revised 18 May 2021; Accepted 20 May 2021

Citation: Kocot-Zalewska J., Woźnica A.J., 2021. Cave-dwelling heleomyzid flies (Diptera: Heleomyzidae) from the Polish caves. Historical overview and new data. International Journal of Speleology, 50(2), 203-211. https://doi.org/10.5038/1827-806X.50.2.2383

\section{INTRODUCTION}

Studies all over the world have been carried out for decades on cavernicolous fauna, with a special interest in hotspot regions (Culver \& Sket, 2000; Culver et al., 2006; Reboleira et al., 2011; Novak et al., 2012; Silva \& Ferreira, 2016; Nitzu et al., 2017; Moldovan et al., 2020; Pipan et al., 2020). These hotspot regions are areas which have a huge number of highly specialised and obligated cave-dwelling species. Discovering new troglobitic species with extreme adaptations to underground environment, engages great activity among biospeleologists (for example, Taglianti, 1996; Edgecombe et al., 2020). Simultaneously, cave areas outside the hotspot regions are definitely less interesting to study, for example, some parts of the north temperate zone. One of the reasons is the lack of or very few obligated cave-dwelling species, which is due to the glacial history in the past geological periods (Demel, 1918; Kowalski, 1955; Culver \& Pipan, 2010). Nevertheless, the caves in these areas have made unique ecosystems with a lot of inhabitants, which are worth knowing. Thus, further studies and analyses help to create the distribution patterns of species in this climate zone.

Poland is a country in Central Europe, and in spite of several cave regions (Fig. 1) hosting a total of 5,200 caves (Gradziński \& Kicińska, 2017), there are still many gaps in our knowledge about underground fauna, especially invertebrates. Research on terrestrial invertebrates in caves of Poland dates back to the early $20^{\text {th }}$ century (Kocot-Zalewska \& Domagała, 2020). Most of the studies have been concerned with whole communities of invertebrates in the caves (e.g., Arndt, 1921, 1923; Pax \& Maschke, 1935; Kowalski, 1955; Skalski, 1973, 1981). Few research has been dedicated to groups like springtails (Stach, 1918; Pomorski, 1992), spiders (SanockaWołoszyn, 1963, 1973, 1981), or mites (Maślak \& Barczyk, 2011; Barczyk \& Madej, 2014). Hitherto, no research has been devoted to flies, which are one of the common groups that inhabit the caves and, undoubtedly, the easiest to observe. However, Schmitz (1935) published an article about a new species from the Phoridae family that was collected from the Radochowska Cave, and Klecienko Adit in Sudety Mts. Flies belong to a community that is known as parietal fauna (Košel, 2004; Moseley, 2007) and in Polish literature named "wall fauna" (Kowalski, 1955; Skalski, 1981), which means it lives on the sides of passages and chambers in caves. This community is observed throughout the year, and many species live in caves constantly where they create subterranean populations. Although there have been no reports in literature on the research dedicated only to flies in Polish caves, some information can be found in various articles such as Arndt (1921), Pax \& Maschke (1935), Kowalski (1955), Skalski (1967), Hajduk \& 
Ogorzałek (1970), Sobiepanek (1985), Woźnica (2004), Dumnicka \& Płotek (2013). Summarising those pieces of information, over 60 species of flies have been identified so far (Kocot-Zalewska \& Domagała, 2020), including 17 from the Heleomyzidae family (KocotZalewska \& Woźnica, 2020). Most of these studies had concentrated on a list of species inhabiting caves.

Areas in which studies about invertebrate cavernicolous fauna were performed, are Sudety Mts (Arndt, 1921, 1923; Pax \& Maschke, 1935; Pax, 1937; Hajduk \& Ogorzałek, 1970), Tatra Mts (Kowalski,
1955; Skalski, 1967; Sobiepanek 1985), and KrakówCzęstochowa Upland (Skalski \& Wójcik, 1968; Skalski, 1973, 1981; Papp \& Woźnica, 1993; Woźnica, 2004, 2006; Woźnica \& Klasa, 2009). Unfortunately, in a few cave regions in Poland, i.e., Nida Basin, Carpathian, and Świętokrzyskie Mountains, no studies have been carried out (Fig. 1). Heleomyzid flies have also been reported in a variety of caves in other European countries. Summary of information about heleomyzid flies from European caves is included in Appendix 1.

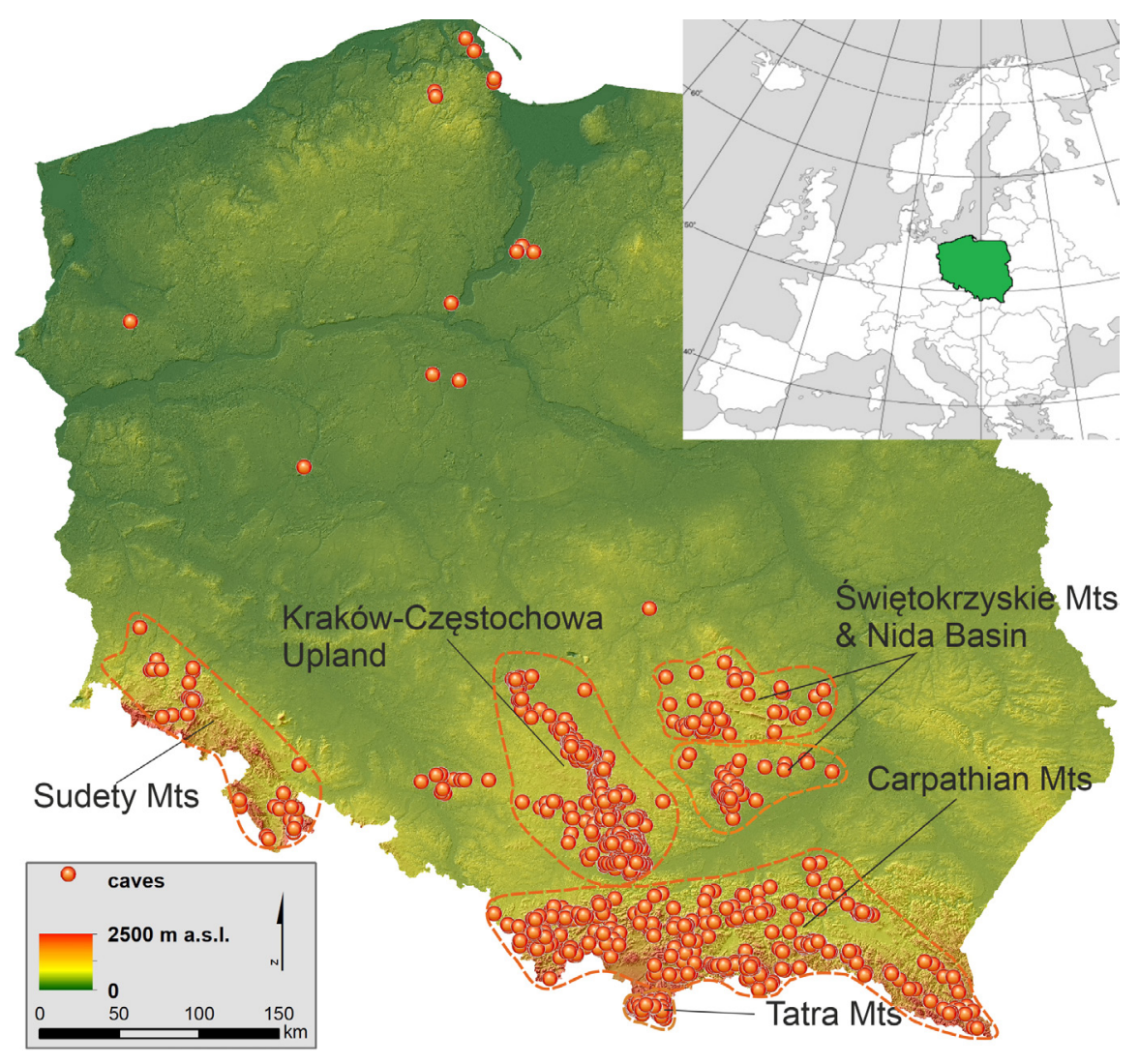

Fig. 1. Map with main cave areas in Poland.

The purpose of this article is to characterize heleomyzid flies occurring in the caves of Poland with emphasis on their ecological classification status, number of species, preference of cave zone, and distribution in different cave areas in Poland.

\section{MATERIAL AND METHODS}

\section{Historical data}

All accessible research papers regarding the heleomyzid flies in the caves of Poland were analyzed. These include works published as monographs, original research papers, notes, and also conference materials. All bibliography can be found in KocotZalewska \& Domagała (2020) and Zatwarnicki (2021).

\section{Current study}

\section{Study area}

The study has been conducted in six caves in the northern part of the Kraków-Czesstochowa Upland in Poland (Fig. 2A). The following caves have been explored: W Zielonej Górze, Towarna, Pod Sokola Góra, Kroczycka, Psia, and Zegar (Fig. 2A, Table 1). All studied caves are rather small. In these caves, the entrance zone can be distinguished, which is a twilight zone with an influence of sunlight (with exception of Kroczycka Cave). The climatic conditions in this zone are evidently synchronised with climatic conditions on the surface. In the middle of the studied caves is dark and climatic conditions are more stable. This part can be classified as a transition zone. Only the last few meters of corridors in these caves can be considered as a deep zone with rather stable climatic conditions, and total darkness (Table 1). More detailed information about climatic conditions can be found in Kocot-Zalewska (2017).

\section{Samples}

The samples were collected from December 2014 through February 2017. The heleomyzid flies were caught in barber traps without any bait but filled with $30 \%$ propylene glycol as a preservative liquid. A direct searching method was also used, but only for corroboration of the flies' composition from cave walls and barber traps. The traps were always placed in the same areas, i.e., in the entrance zone, in the middle of the passages and at the end of the cave (example Fig. 2B). The specimens were collected from the traps 

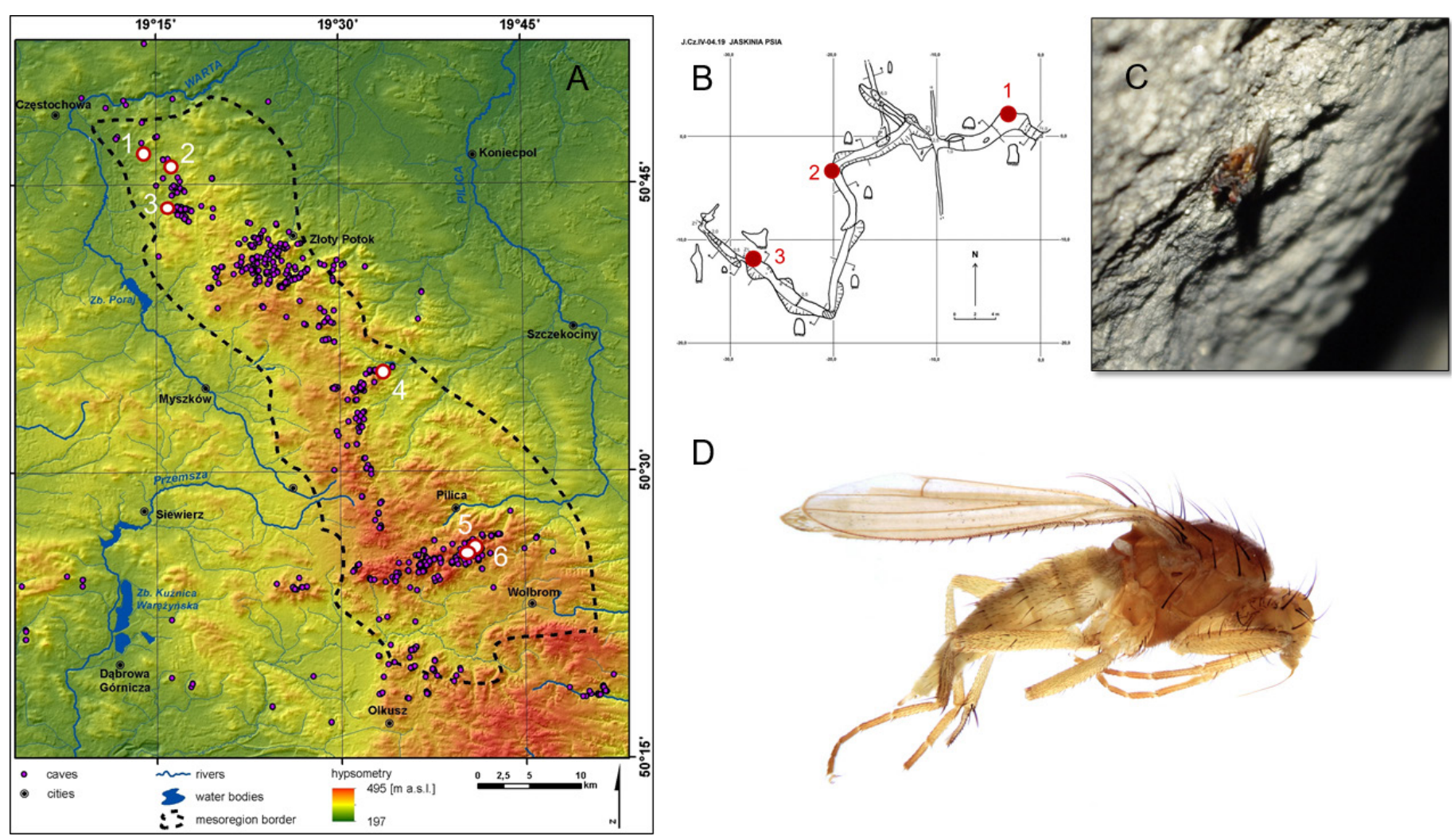

D

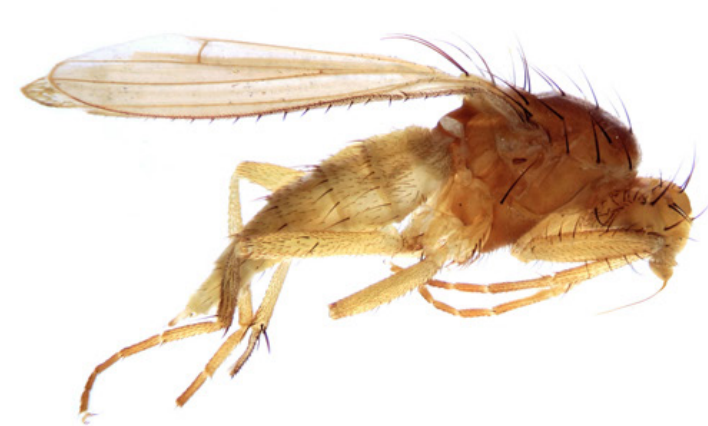

Fig. 2. A) Map of the studied area with collecting caves indicated: 1. W Zielonej Górze, 2. Towarna, 3. Pod Sokolą Górą, 4. Kroczycka, 5. Psia, 6. Zegar; B) An example of a cave plan (Psia) with marked places where pitfall traps were situated (cave plan by Polonius, from: Grodzicki, 2011); C) A pair of copulated Heleomyza captiosa in the Zegar Cave; D) Female of Scoliocentra confusa - a rare heleomyzid fly collected on 19.01 .2015 in Psia Cave.

Table 1. The basic geographical and environmental data on the studied caves.

\begin{tabular}{|c|c|c|c|c|c|c|}
\hline $\begin{array}{l}\text { Cave number } \\
\text { on the map }\end{array}$ & The cave & $\begin{array}{l}\text { Altitude } \\
\text { m.a.s.1. }\end{array}$ & $\begin{array}{c}\text { Entrance size } \\
\text { height and width } \\
(m \times \mathrm{m})\end{array}$ & $\begin{array}{l}\text { The length of } \\
\text { corridors (m) }\end{array}$ & $\begin{array}{c}\text { Average annual } \\
\text { temperature inside } \\
\text { the cave }\left({ }^{\circ} \mathrm{C}\right)\end{array}$ & $\begin{array}{l}\text { Average annual RH } \\
\text { inside the cave (\%) }\end{array}$ \\
\hline 1 & W Zielonej Górze & 316 & $1.3 \times 2$ & 140 & 7.2 & 90 \\
\hline 2 & Towarna & 330 & $2 \times 2$ & 109 & 8.0 & 91 \\
\hline 3 & Pod Sokola & 342 & $2 \times 3$ & 70 & 4.4 & 96 \\
\hline 4 & Kroczycka & 380 & $0.5 \times 0.5$ & 60 & 5.9 & 89 \\
\hline 5 & Psia & 408 & $1.5 \times 1$ & 85 & 6.8 & 85 \\
\hline 6 & Zegar & 426 & $2 \times 1$ & 155 & 5.8 & 90 \\
\hline
\end{tabular}

monthly throughout 2015. The collection method was changed in 2016 when the traps were used for a fortnight but were collected every other month.

The material was kept in plastic vials using 70\% ethanol. All specimens were identified using various keys, especially those made by Czerny (1924) - mainly for species of the genus Suillia, and those made by Gorodkov (1970), especially for Heleomyza species. The material is stored in the collection of the Upper Silesian Museum in Bytom (pl. Jana III Sobieskiego 2, 41-902 Bytom, Poland).

The picture of the female specimen of Scoliocentra confusa was taken with a Canon 600d digital camera attached to Nikon SMZ stereomicroscope, using computer graphic techniques (Corel Draw X6) and a photo stacking method (Helicon Focus ver. 7).

The temperature was measured by using Assmann psychrometer in four constant points; the first one was localised outside the caves close to the cave entrance, and three inside the caves, according to the place of traps (Fig. 2B). The average annual RH value inside the cave was ascertained based on psychrometric tables.

\section{Methods of the ecological analyses}

For ecological analyses, the number of species with sample sizes were used for each of the studied caves. Dominance and faunistic similarity index were calculated. The analysis of the dominant species was based on the number of specimens in the total sample. The ecological classification was based on Sket's (2008) concept. To evaluate the similarity of heleomyzid flies' community, the Jaccard index and Ward's method with Euclidean distance were used. These analyses were made by using Past3 software.

\section{RESULTS}

\section{Historical overview}

So far, 17 species from Polish caves are known. The species list is presented in Table 2. The highest number of species were found in the Tatra Mts and in the Kraków-Częstochowa Upland. The least number of species was collected in the Sudety Mts. Additionally, the occurrence of Oecothea praecox Loew (1862) in the Polish part of the Sudety area is currently doubtful since no specimens have been found in the museum 
collections and neither specimen has been caught in the Polish caves after the Second World War (Košel \& Woźnica, 2019). Nonetheless, there is no data about heleomyzid flies in the caves of Świetokrzyskie Mts, Nida Basin, Carpathian Mts (Fig. 1).

\section{Current data}

In total, 179 specimens of heleomyzid flies have been collected, which belong to 16 species. However, in the first season, 14 species were detected, and 12 in the second. The checklist of species is listed in Table 2. Seven species were common for both years. These were: Eccoptomera obscura, E. pallescens, Heleomyza captiosa, $H$. serrata, Oecothea fenestralis, Scoliocentra brachypterna, S. villosa. The following species were dominant: Scoliocentra brachypterna, Heleomyza captiosa, and Eccoptomera pallescens (Fig. 3). Among 23 heleomyzid species known from Polish caves, 1 has been regarded as eutroglobiont, 11 as eutroglophiles, 9 as subtroglophiles, and 2 as trogloxenes (Table 2).
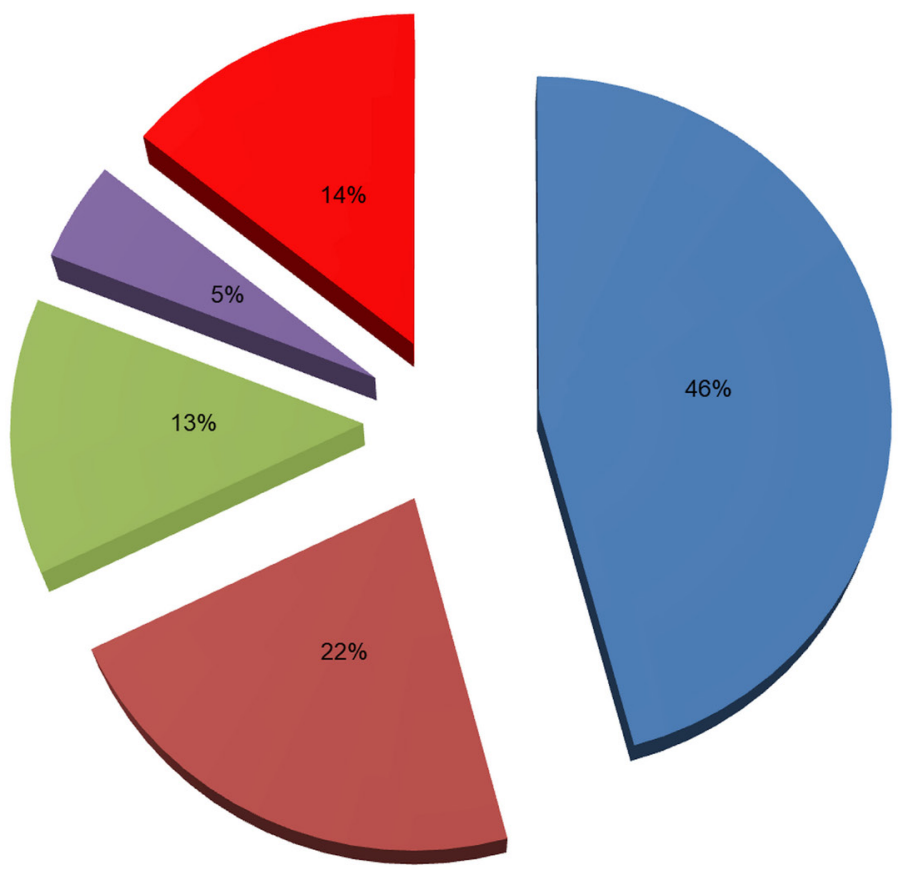

- Scoliocentra brachypterna

- Heleomyza captiosa

Eccoptomera pallescens

- Scoliocentra villosa

athers

Fig. 3. Species domination reflected by species composition (important value), dominance index.

Table 2. The list of the heleomyzid flies occurring in the Polish caves; grey field - historical data; black field - new data; and ecological classification.

\begin{tabular}{|c|c|c|c|c|c|}
\hline \multirow[b]{2}{*}{ No. } & \multirow[b]{2}{*}{ Species' name } & \multicolumn{3}{|c|}{ Occurrence of the species in the regions } & \multirow{2}{*}{$\begin{array}{l}\text { Ecological } \\
\text { classification }\end{array}$} \\
\hline & & Tatra Mts & Sudety Mts & $\begin{array}{c}\text { Kraków-Częstochowa } \\
\text { Upland }\end{array}$ & \\
\hline 1 & Eccoptomera emarginata Loew, 1862 & & & & eutroglophile \\
\hline 2 & Eccoptomera longiseta Loew, 1862 & & & & subtroglophile \\
\hline 3 & Eccoptomera obscura (Meigen, 1830) & & & & subtroglophile \\
\hline 4 & Eccoptomera ornata Loew, 1862 & & & & subtroglophile \\
\hline 5 & Eccoptomera pallescens (Meigen, 1830) & & & & eutroglophile \\
\hline 6 & Gymnomus amplicornis (Czerny, 1924) & & & & subtroglophile \\
\hline 7 & Gymnomus caesius (Meigen, 1830) & & & & eutroglophile \\
\hline 8 & Gymnomus ceianui (Martinek, 1985) & & & & subtroglophile \\
\hline 9 & Gymnomus czernyi Papp et Woźnica, 1993 & & & & subtroglophile \\
\hline 10 & Gymnomus sabroskyi (Gill, 1962) & & & & eutroglophile \\
\hline 11 & Gymnomus spectabilis (Loew, 1862) & & & & eutroglophile \\
\hline 12 & Heleomyza captiosa (Gorodkov, 1962) & & & & eutroglophile \\
\hline 13 & Heleomyza modesta (Meigen, 1835) & & & & sutroglophile \\
\hline 14 & Heleomyza serrata (Linnaeus, 1758) & & & & eutroglophile \\
\hline 15 & Heteromyza atricornis Meigen, 1830 & & & & eutroglophile \\
\hline 16 & Oecothea fenestralis (Fallén, 1820) & & & & eutroglophile \\
\hline 17 & Oecothea praecox Loew, 1862 & & & & eutroglobiont \\
\hline 18 & Scoliocentra brachypterna (Loew, 1873) & & & & eutroglophile \\
\hline 19 & Scoliocentra confusa (Wahlgren, 1918) & & & & subtroglophile \\
\hline 20 & Scoliocentra dupliciseta (Strobl, 1894) & & & & subtroglophile \\
\hline 21 & Scoliocentra villosa (Meigen, 1830) & & & & eutroglophile \\
\hline 22 & Suillia bicolor (Zetterstedt, 1838) & & & & trogloxene \\
\hline 23 & Suillia lineitergum (Pandellé, 1901) & & & & trogloxene \\
\hline
\end{tabular}


An analysis of species richness has been made. In the Kroczycka and Towarna caves, there were only 3-4 species observed. In these caves, an abundance of the heleomyzid flies was also the least numerous. Whereas in the Psia and Zegar caves, seven species per cave were collected and a high number of specimens (Fig. 4).

The species richness and abundance analyses have also been made according to the cave zones, and altogether for all studied caves. In the entrance zones, the highest number of species was noticed, however, the highest number of specimens was observed in the middle of the caves and at the end of the caves. In the immediate surroundings of the caves, the lowest number of species, as well as specimens, was found (Fig. 5).

An average annual air temperature inside the caves was $6-7^{\circ} \mathrm{C}$, while outside the caves, the average annual temperature was higher; $9^{\circ} \mathrm{C}$ (Fig. 5). The coldest cave is Pod Sokola with an average annual temperature ca $4.4^{\circ} \mathrm{C}$ (Table 1). More significant differences concerned average annual amplitude of temperature. In the entrance zone it was $26^{\circ} \mathrm{C} ; 14^{\circ} \mathrm{C}$ in the middle of the passages, and $5^{\circ} \mathrm{C}$ at the end of the caves. Whereas outside the caves it was $37^{\circ} \mathrm{C}$.

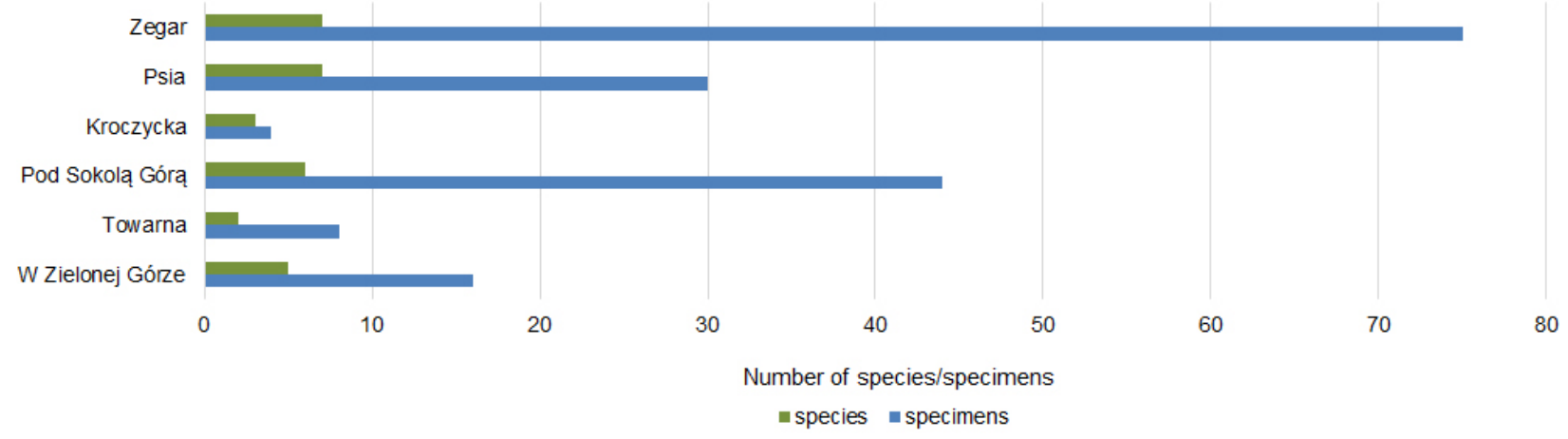

Fig. 4. Species richness and abundance of the Heleomyzidae family in studied caves.

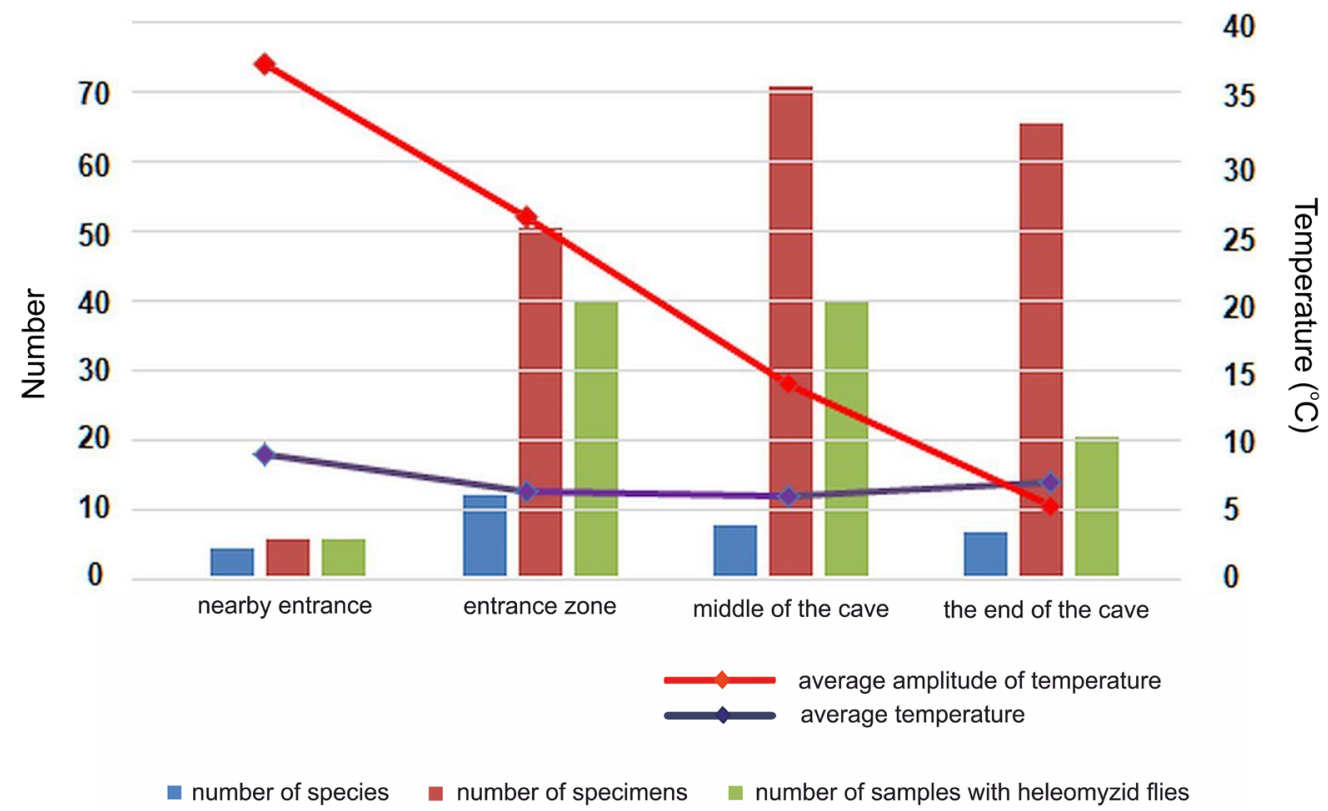

Fig. 5. Species richness and abundance of the Heleomyzidae family according to the cave' zone, and average annual air temperature and annual amplitude of temperature.

The faunistic similarity analyses have been performed using the Jaccard index (Fig. 6A) and Ward's method with Euclidean distance (Fig. 6B). The analysis of faunistic similarity indicates that the Psia, Pod Sokola, and W Zielonej Górze caves are rather alike, whereas the Towarna Cave is dissimilar to other caves. The analysis of the faunistic distance clearly shows two groups of caves. One of them assemblages four caves (Fig. 6B), among which the three most similar caves are (Fig. 6A).

\section{DISCUSSION}

Based on historical data and this study, an update of a checklist of heleomyzid flies inhabiting caves in different regions of Poland has been presented. Currently, the list concerns 23 species belonging to seven genera (Table 2).

The highest diversity of species has been identified in the entrance zone of caves, and the fewest at the end of these; this is typical for non-troglobiont fauna (e.g., Skalski, 1973; Tobin et al., 2013). Despite lower species' richness in deep parts of the caves, there occurred communities of the largest number of specimens. It might be due to the relative stability of climatic conditions, like temperature. The temperature amplitude was lower by half in the middle of the caves in relation to the entrance zone, and much lower at the end of the caves with a result of $5^{\circ} \mathrm{C}$. The lowest species richness as well as species abundance was 


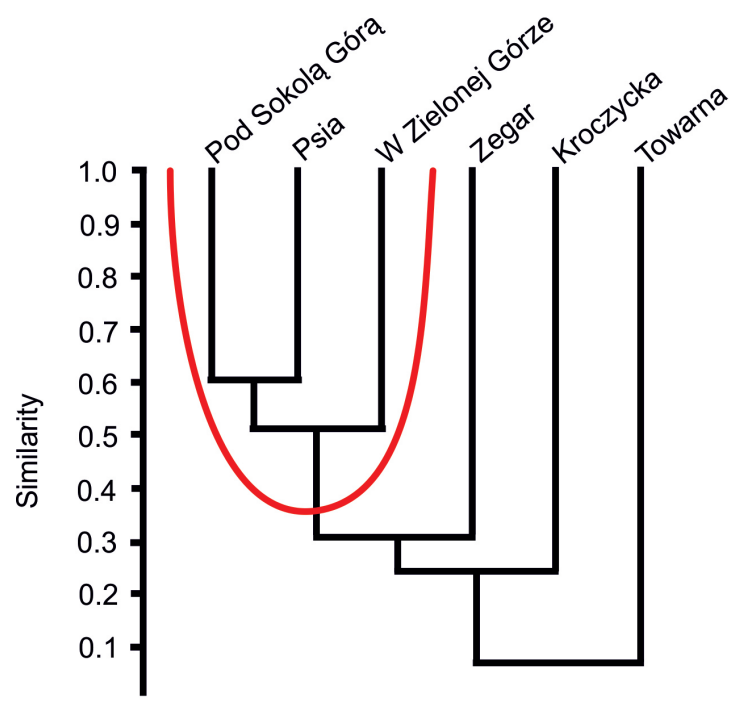

A

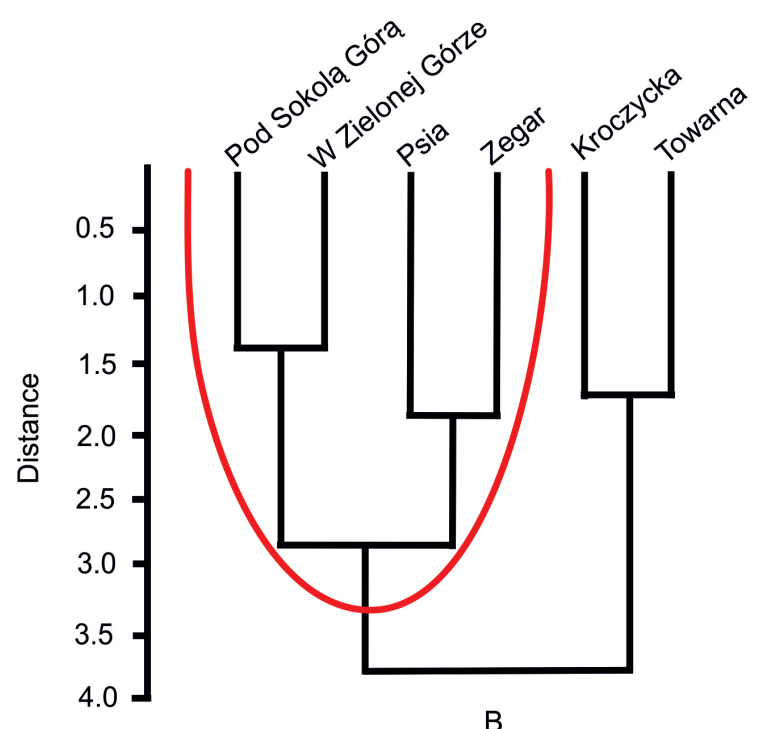

B

Fig. 6. A) The faunistic similarity of heleomyzid species composition (Jaccard index); B) The faunistic distance of heleomyzid species composition (Ward's method with Euclidean distance) in the studied caves.

observed outside the caves near the entrances. It is hard to explain because most of the entrances were surrounded by forest, and only one (Towarna) lies at the top of the hill in an unforested area. Therefore, this environment should promote occurrence of heleomyzid species, which prefer cool and shaded places to live, and their larval stages are related to fungi and decaying matter (Dely-Draskovits, 1972; Lo Giudice \& Woźnica, 2013). Perhaps very high diurnal and annual amplitude of air temperature or air humidity fluctuations are the reasons for sparce occurrence in this particular area. More research is needed to get a detailed explanation.

Looking at the number of specimens in these particular caves, we could address the fauna in the Zegar, Psia, and Pod Sokola caves. All these caves have large entrance zones (Table 1), which promote the penetration of fauna. These caves also have the highest degree of similarity among studied caves, as well as forming a common group in Ward's method. According to the Jaccard's index, the most similar fauna occurred in the Pod Sokola and the Psia caves. It should be noted that in both caves, a very rare species, Scoliocentra confusa was present (Fig. 2D). This is a boreal-montane species with an unknown biology, hitherto recorded in South Poland only (Woźnica, 2007). The faunistic distance corresponds to the geographic distance (Fig. 2A, 6B) except for the Towarna and Kroczycka caves. The first one lies in the northern part of the study area and the second in the centre. Both characterise a small number of species.

The three dominant species: Scoliocentra brachypterna, Heleomyza captiosa, and Eccoptomera pallescens also have a strong affinity for the winter season and could be classified as a snow species (Soszyńska-Maj \& Woźnica, 2016). The low temperature inside the cave combined with the occurrence of bat guano promotes the settlement of these insects. Bat guano is common in the Częstochowa Upland caves as a consequence of winter occurrence of many bat species (Postawa \& Ignaczak, 2017). It was also observed in studied caves (unpublished data).
This in turn, favours the philopatry in subsequent generations, effects in making stable populations inside the caves. Populations created by the same above-mentioned species are also found in other cave regions, for example, in Slovak caves (Košel, 2004). All dominant species are typical European taxa; Central Europe is the centre of their occurrence. The larval stages of Scoliocentra brachypterna and Heleomyza captiosa develop in bat or bird guano (Beron et al., 2011), which explains their abundance in the caves in mountainous regions, like Tatra Mts (Kowalski, 1955).

What is remarkable is the absence of cold-preferring species from the genus Heteromyza in the studied caves. The lack of Heteromyza species could be explained by the relatively high temperature inside the caves, which is between $6-8^{\circ} \mathrm{C}$ (Skalski, 1994/1995; Dumnicka \& Płotek, 2013; Kocot-Zalewska, 2017). Additionally, the studied caves are small and limestone-built. During the day, limestone heats well, but then it loses its temperature very quickly, so the daily temperature amplitude is high. It could have a significant impact on larval stages of this genus. The cold-preferring genus Heteromyza was collected from Tatra Mts, where the annual mean temperature in the caves was lower, between $2.5-5.5^{\circ} \mathrm{C}$ (Kowalski, 1955). The difference to air temperature and its amplitude in caves in above-mentioned regions, results from caves location in these regions as well as local climate. The entrances of the caves in Tatra Mts lie high, above 1,000 m.a.s.1. (Kowalski, 1955), while the entrances of the Czestochowa Upland lie definitely lower, 300400 m.a.s.1. (Szelerewicz \& Górny, 1986). Moreover, the Czestochowa Upland is significantly warmer than Tatra Mts (Kondracki, 2002).

Determining heleomyzid' ecological classification, its occurrence in both seasons and inhabiting different parts of caves were taken. Concerning species from historical data, firstly, the collection sites from the literature were analysed and, secondly, the classification of heleomyzid flies by Zaenker et al. (2020) was used. The species, considered as eutroglophiles, have been collected during both seasons in all zones of the caves, for example, Scoliocentra brachypterna 
and Eccoptomera pallescens. These species are also known as eutroglophiles from subterranean areas in other countries (Zaenker et al., 2020). Although Eccoptomera obscura was not included in this group, despite its occurrence in both seasons, it was detected only in the entrance zone of the studied caves. This species was considered as subtroglophile, the same classification can be found in Zaenker et al. (2020). The species that were reported during only one season, but in deeper zones of the caves, were recognised as subtroglophiles, for instance, Scoliocentra confusa. The species that only occurred in the entrance zone of the caves, for example, Suillia bicolor were considered to be trogloxenes. Our ecological classification of heleomyzid flies is mostly similar to this by Zaenker et al. (2020). However, there are some differences, for example we considered Eccoptomera pallescens and Gymnomus caesius as eutroglophile, while Zaenker et al. (2020) as a subtroglophile. In turn, we recognized Heleomyza modesta and Scoliocentra dupliseta as subtroglophile, whereas Zaenker et al. (2020) as a eutroglophile.

The specimens of the Suillia genus could occur in caves accidentally. They are a mycotrophic species and may develop in the entrance zones, where fungi often occur. In the case of the other species of heleomyzid flies, that have been found in the studied caves (e.g., Eccoptomera sp., Gymnomus sp., or Heleomyza sp.), their larval development is associated with rodents' burrows, and other mammals living in forest ecosystems (Soszyńska-Maj \& Woźnica, 2016). So, these could provide reasons for why they also live in the caves, even in the dark parts (e.g., Gymnomus caesius and G. amplicornis in the Slovakian caves; Košel, 2004).

We can assume that the Diptera, including the Heleomyzidae family occurring in the caves of the Kraków-Częstochowa Upland, consists of relatively young fauna. During the glaciation periods, the Częstochowa Upland was not completely covered by a continental glacier, but the whole region had been influenced by a periglacial climate, thereafter fluvioglacial sediments filled hollows which composed of sand and gravel layers (Lewandowski, 2009). However, over Pliocene and Pleistocene, changes in the climate ensued several times in the aftermath of consecutive phases - stadials and interstadials of glaciations. As a result, the faunal composition was modified a few times, and the effects can now be observed in vertebrate bones found in layers. Particularly insectivore fauna bones are interesting because they prove the occurrence of insects. But what is remarkable is that there is a gap in fauna residues that reveals a period of approximately 0.5 million years (Stefaniak et al., 2009). This indicates the most intensive impact of San II glaciation during which no fauna occupied this region. To sum up, modern fauna, including heleomyzid flies, had to inhabit this region not earlier than after the San II glaciation.

The highest number of species has currently been found in the Kraków-Częstochowa Upland. However, this is not a conclusive result because research has not been conducted in this subject for a long time in other cave regions; in several regions, research has not yet been undertaken at all.

\section{ACKNOWLEDGEMENT}

The material was collected with permission of Regional Directorate for Environmental Protection (RDOŚ) in Katowice: WPN.6205.49.2014.MM, WPN.6401.484.2014.MS, and Kraków: OP-I.6401. 2.2015.MMr. We are grateful to Leonora Ippolito for the revision of the English. We also thank the reviewers for their careful reading of our manuscript and their many insightful comments and precious suggestions.

Authorship statement: JK-Z: the idea of the article, collected the data, performed the ecological analysis, wrote the text, AJW: determined the species, performed a historical overview, wrote the text.

\section{REFERENCES}

Arndt, W., 1921. Beitrag zur Kenntnis der Höhlenfauna. Ergebnis einer faunistischen Untersuchung der Höhlen Schlesiens. Zoologischer Anzeiger, 52(12-13), 310-315. Arndt, W., 1923. Speläobiologische Untersuchungen in Schlesien. Speläologische Jahrbuch, 4, 95-114.

Barczyk, G., Madej, G., 2014. Comparison of the species composition of Gamasina mite communities (Acari, Mesostigmata) in selected caves of the KrakówCzestochowa Upland (southern Poland) and their immediate surroundings. Journal of Natural History, 49(27-28), 1673-1688. https://doi.org/10.1080/00222933.2014.976667

Culver, D.C., Pipan, T., 2010. Climate, abiotic factors, and the evolution of subterranean life, Acta Carsologica, 39(3), 577-586. https://doi.org/10.3986/ac.v39i3.85

Culver, D.C., Sket, B., 2000. Hotspots of subterranean biodiversity in caves and wells. Journal of Cave and Karst Studies, 62, 11-17.

Culver, D.C., Deharveng, L., Bedos, A., Lewis, J.J., Madden, M., Reddell, J.R., Sket, B., Trontelj, P., White, D., 2006. The mid-latitude biodiversity ridge in terrestrial cave fauna. Ecography, 29, 120-128.

https://doi.org/10.1111/j.2005.0906-7590.04435.x

Czerny, L., 1924. Monographie der Helomyziden (Dipteren). (Mit einer Tafel von Direktor Friedrich Hendel). Abhandlungen der Zoologisch-Botanischen Gesellschaft in Österreich, 15(1), 1-166.

Dely-Draskovits, A., 1972. Systematische und ökologische Untersuchungen an den in Ungarn als Schädlinge der Hutpilze auftretenden Fliegen IV. Trichoceridae, Scatopsidae, Heleomyzidae, Anthomyzidae (Diptera). Acta Zoologica Hungarica, 18(3-4), 283-290.

Demel, K., 1918. Fauna jaskiń Ojcowskich. Sprawozdania z posiedzeń Towarzystwa Naukowego Warszawskiego, Wydział Nauk Matematyczno-Przyrodniczych, 11(4), 623-659.

Dumnicka, E., Płotek, M., 2013. Antropogeniczne zmiany fauny bezkręgowców jaskiń Gór Towarnych (Wyżyna Krakowsko-Częstochowska). Chrońmy Przyrodę Ojczysta, 69, 285-296.

Edgecombe, G.D., Akkari, N., Netherlands, E.C., Du Preez, G., 2020. A troglobitic species of the centipede Cryptops (Chilopoda, Scolopendromorpha) from northwestern Botswana. ZooKeys, 97, 25-40. https://doi.org/10.3897/zookeys.977.57088 
Gorodkov, K.B., 1970. Semya Helomyzidae (Heleomyzidae). In: Stackelberg, A.A., Nartshuk, E.P. (Eds.). Opredelitel nasekomych Evropejskoi chasti SSSR, 5(2), 306-325 (In Russian).

Gradziński, M., Kicińska, D., 2017. Caves in Poland. In: Kicińska, D. (Ed.). Polish caving 2013-2017. Published on the occasion of the $17^{\text {th }}$ International Congress of Speleology, p. 4-6.

Grodzicki, J. (Ed.), 2011. Jaskinie Wyżyny Częstochowskiej t. 4. Jaskinie Pasma SmoleńskoNiegowonickiego, Wydawnictwo PTPNoZ, Warszawa, $368 \mathrm{p}$.

Hajduk, Z., Ogorzałek, A., 1970. Wyniki badań faunistycznych Jaskini Niedźwiedziej. Acta Universitatis Wratislaviensis, 127, Studia geograficzne, 14, 79-84.

Kocot-Zalewska, J., 2017. Kształtowanie się mikroklimatu w wybranych jaskiniach Wyżyny Częstochowskiej. Acta Geographica Silesiana, 11/1(25), 11-21.

Kocot-Zalewska, J., Domagała, P., 2020. Terrestrial invertebrate fauna of Polish caves - a summary of 100 years of research. Subterranean Biology, 33, 45-69. https://doi.org/10.3897/subtbiol.33.48805

Kocot-Zalewska, J., Woźnica, A.J., 2020. Heleomyzidae (Diptera) in the caves of Poland. Historical overview and new data. ARPHA Conference Abstracts 3: Article ID e52665. https://doi.org/10.3897/aca.3.e52665

Kondracki, J., 2002. Geografia regionalna Polski. Wydawnictwo Naukowe PWN, Warszawa, $441 \mathrm{p}$.

Košel, V., 2004. Parietal Diptera in caves of the Belianske Tatry Mts (Slovakia, the Western Carpathians) I. Introduction and species spectrum. Acta Facultatis Ecologiae, 12(1), 69-73.

Košel, V., Woźnica, A.J., 2019. First record of Oecothea praecox (Loew, 1862) (Diptera, Heleomyzidae) from Slovakia. Dipteron - Bulletin of the Dipterological Section of the Polish Entomological Society, 35, 72-79. https://doi.org/10.5281/zenodo.3520154

Kowalski, K., 1955. Fauna jaskiń Tatr Polskich. Ochrona Przyrody, 23, 283-333.

Lewandowski, J., 2009: Cenozoic development of the Czestochowa Upland - disputable problems. In: Stefaniak, K., Tyc, A., Socha, P. (Eds.), Karst of the Częstochowa Upland and of the Eastern Sudetes: palaeoenvironments and protection. Studies of the Faculty of Earth Sciences, University of Silesia, No. 56, Sosnowiec - Wrocław, p. 85-144.

Lo Giudice, G., Woźnica, A.J., 2013. An updated checklist of the Italian Heleomyzidae (Diptera: Sphaeroceroidea). Genus, 24(3-4), 439-458.

Maślak, M., Barczyk, G., 2011. Oribatid mites (Acari, Oribatida) in selected caves of the Kraków-Wielun Upland (southern Poland). Biological Letters, 48(1), 107116. https://doi.org/10.2478/v10120-011-0011-y

Moldovan, O.T., Iepure, S., Brad, T., Kenesz, M., Mirea, I.C., Năstase-Bucur, R., 2020. Database of Romanian cave invertebrates with a Red List of cave species and a list of hotspot/coldspot caves. Biodiversity Data Journal 8: e53571. https://doi.org/10.3897/BDJ.8.e53571

Moseley, M., 2007. Acadian biospeleology: composition and ecology of cave fauna of Nova Scotia and southern New Brunswick, Canada. International Journal of Speleology, 36(1), 1-21.

https://doi.org/10.5038/1827-806X.36.1.1

Nitzu, E., Vlaicu, M., Giurginca, A., Meleg, I.N., Popa, I., Nae, A., Baba, Ş., 2018. Assessing preservation priorities of caves and karst areas using the frequency of endemic cave-dwelling species. International Journal of Speleology, 47(1), 43-52.

https://doi.org/10.5038/1827-806X.47.1.2147
Novak, T., Perc, M., Lipovšek, S., Janžekovič, F., 2012. Duality of terrestrial subterranean fauna. International Journal of Speleology, 41, 181-188. https://doi.org/10.5038/1827-806X.41.2.5

Papp, L., Woźnica, A.J., 1993. A revision of the Palaearctic species of Gymnomus LOEW (Diptera: Heleomyzidae). Acta Zoologica Hungarica, 39, 175-210.

Pax, F., Maschke, K., 1935. Höhlenfauna des Glatzer Schneeberges. Die rezente Metazoenfauna. Beiträge zur Biologie des Glatzer Schneeberges, 1, 4-72.

Pax, F., 1937. Höhlenfauna des Glatzer Schneeberges. Wandlungen des Tierlebens in der Wolmdorfer Tropfsteinhöhle. Beiträge zur Biologie des Glatzer Schneeberges, 3, 289-293.

Pipan, T., Deharveng, L., Culver, D.C., 2020. Hotspots of Subterranean Biodiversity. Diversity, 12(5), 209. https://doi.org/10.3390/d12050209

Pomorski, R., 1992. Collembola of caves and some adits of the polish Sudetes. Acta Universitatis Vratislaviensis, 1359, Prace Zoologiczne, 25, 27-44.

Postawa,T., Ignaczak M., 2017. Miejsca rojenia nietoperzy na Wyżynie Częstochowskiej i Wyżynie Wieluńskiej. Przegląd Przyrodniczy XXVIII, 3, 87-95.

Reboleira, A.S., Paulo, P.S., Borges, A.V., Gonçalves, F., Serrano, A.R.M., Oromí, P., 2011. The subterranean fauna of a biodiversity hotspot region - Portugal: an overview and its conservation. International Journal of Speleology, 40, 23-37.

https://doi.org/10.5038/1827-806X.40.1.4

Sanocka-Wołoszyn, E., 1963. Uwagi nad rozmieszczeniem i ekologią pająków (Araneae) z jaskiń Gór Świętokrzyskich. Seminarium Speleologiczne I Ogólnopolskiego Zjazdu Badaczy Krasu, Święta Katarzyna, Polska, 73-85.

Sanocka-Wołoszyn, E., 1973. Ischyropsalis hellwigi (Panzer, 1794) (Opiliones) z Ojcowskiego Parku Narodowego. Przeglad Zoologiczny, 17, 49-52.

Sanocka-Wołoszynowa, E., 1981. Badania pajęczaków jaskiń Wyżyny Krakowsko-Częstochowskiej. Acta Universitatis Wratislaviensis, 486, Prace Zoologiczne, $11,1-90$.

Schmitz, H., 1935. Die Höhlenfauna des Glatzer Schneeberges 3. Neue Phoriden aus der Tropfsteinhöhle und dem Stollen in Neu-Klessengrund. Beitrage zur Biologie des Glatzer Schneeberges, 1, 75-79.

Skalski, A.W., 1967. Characteristics of the recent fauna from the Szczelina Chochołowska cave in the Tatra Mts. Prace Muzeum Ziemi, 11, 288-290.

Skalski, A.W., 1973. Materiały do znajomości bezkręgowców jaskiń Wyżyny KrakowskoCzęstochowskiej. Rocznik Muzeum Częstochowskiego, 3, 161-200.

Skalski, A.W., 1981. Charakterystyka fauny podziemnej Wyżyny Krakowsko-Częstochowskiej. Rocznik Muzeum Okręgowego w Częstochowie, 5, Przyroda, 2, 51-60.

Skalski, A.W., 1994/1995. Obserwacje nad termika jaskini Pod Sokola w rezerwacie „Sokole Góry” w pobliżu Olsztyna k. Częstochowy. Prace i Materiały Muzeum im. Prof. Wł. Szafera, Pradnik, 9, 17-30.

Skalski, A.W., Wójcik, Z., 1968. Jaskinie rezerwatu Sokole Góry w okolicy Częstochowy. Ochrona Przyrody PAN, 237-275.

Sket, B., 2008. Can we agree on an ecological classification of subterranean animals? Journal of Natural History, 42(21), $1549-1563$. https://doi.org/10.1080/00222930801995762

Sobiepanek, E., 1985. Fauna jaskiń tatrzańskich. In: Amirowicz, A., Baryła, J., Dumnicki, L. (Eds.), Materiały XV Sympozjum Speleologicznego, Gacek, 71-73. 
Silva, M.S., Ferreira, R.L., 2016. The first two hotspots of subterranean biodiversity in South America. Subterranean Biology, 19, 1-21. https://doi.org/10.3897/subtbiol.19.8207

Soszyńska-Maj, A., Woźnica, A.J., 2016. A case study of Heleomyzidae (Diptera) recorded on snow in Poland with a review of their winter activity in Europe. European Journal of Entomology, 113, 279-294. https://doi.org/10.14411/eje.2016.035

Stach, J., 1918. Skoczogonki jaskiń Ojcowa. Rozprawy Wydziału Matematyczno-Przyrodniczego Akademii Umiejętności, 58B, 371-387.

Stefaniak, K., Nadachowski, A., Tomek, T., Socha, P., 2009. Palaeontological studies in the Czestochowa Upland. In: Stefaniak, K., Tyc, A., Socha, P. (Eds.), Karst of the Częstochowa Upland and of the Eastern Sudetes: palaeoenvironments and protection. Studies of the Faculty of Earth Sciences, University of Silesia, No. 56, Sosnowiec - Wrocław, p. 85-144.

Szelerewicz, M., Górny, A., 1986. Jaskinie Wyżyny Krakowsko-Wieluńskiej. PTTK "Kraj”, Kraków, 200 p.

Taglianti, A.V., 1996. A new genus and species of troglobitic Trechinae (Coleoptera, Carabidae) from southern China. International Journal of Speleology, 25: 33-41. https://doi.org/10.5038/1827-806X.25.1.3

Tobin, B.W., Hutchins, B.T., Schwartz, B.F., 2013. Spatial and temporal changes in invertebrate assemblage structure from the entrance to deep-cave zone of a temperate marble cave. International Journal of Speleology, 42(3), 203-214.

https://doi.org/10.5038/1827-806X.42.3.4

Woźnica, A.J., 2004. Redescription of Scoliocentra (Leriola) brachypterna (Loew, 1873) (Diptera: Heleomyzidae) with description of a new species from Europe. Polskie Pismo Entomologiczne, 73, 327-338.

Woźnica, A.J., 2006. Gymnomus caucasicus a new species of Heleomyzid flies from Caucasus Mountains (Diptera: Heleomyzidae). Genus, 17(3), 399-408.

Woźnica, A.J., 2007. Błotniszkowate (Heleomyzidae). In: Bogdanowicz, W. et al. (Eds.), Fauna Polski, Charakterystyka i wykaz gatunków, II, p. 124-126, 211-213.

Woźnica, A.J., Klasa, A., 2009. Heleomyzid flies of the Ojców National Park, with notes on Suillia lineitergum (Pandellé, 1901) - a species new to the Fauna of Poland (Diptera: Heleomyzidae). Fragmenta Faunistica, 52(2), 181-190. https://doi.org/10.3161/00159301FF2009.52.2.181

Zaenker, S., Weber, D., Weigand, A., 2020. Liste der cavernicolen Tierarten Deutschlands mit Einschluss der Grundwasserfauna (Version 1.9). [accessed 27.04.2020]. Available from URL: https://www.hoehlentier.de/taxa.pdf

Zatwarnicki, T., 2021. Bibliografia Dipterologiczna Polski (1597-2020). Polish Dipterological Bibliography (15972020). Dipteron, 37(01), 1-361. https://doi.org/10.5281/zenodo.4410829 